medal, executed by Mr. Percy Metcalfe, is to be awarded annually to the best student in geology in his final year, but the first copy was presented to Mrs. Watts. In making the presentations on behalf of the fifty members of staff who have served in the Department of Geology during the last twenty-five years, Prof. P. G. H. Boswell recalled Prof. Watts's high distinction as an original investigator, and referred to the great influence he has exercised on British geology in his time. Geology generally has benefited by Prof. Watts's well-known capacity for organisation and administration and by his genius as a teacher, in which field he is felicissime princeps. Prof. Watts, in returning thanks, acknowledged the encouragement and help he had received from his teachers and associates, and took the opportunity of announcing the establishment of a prize-fund in memory of his predecessor, Prof. J. W. Judd. In a characteristically happy speech, he charged his old students and staff with having used, when they turned their microscopes on him, only low powers and parallel nicols, so that they saw a gorgeous display of colour, but failed to observe his angle of extinction.

\section{Geology in International Affairs}

On Feb. 18, Prof. H. H. Read, George Herdman professor of geology in the University of Liverpool, delivered his inaugural address. In discussing certain aspects of geology, both national and international, Prof. Read stated that the importance of mineral deposits in national and international affairs arises from three main factors, namely, the irregular distribution of minerals among the nations, their character as irreplaceable wasting assets, and the gigantic acceleration in their consumption. A survey of the present and future mineral position shows that the British Empire, provided it remains a unit of intelligent type, and the United States are together overwhelmingly dominant. The Empire's chief lack is petroleum, a circumstance giving added importance to the production of oil from coal. The dominance of these two units leads to the consideration of schemes for the prevention of war, similar to those suggested by Sir Thomas Holland. A mineral sanction, or an agreement by the United States and the British Empire not to export key minerals to disturbers of the peace would prevent, stop, or at least limit, war.

\section{Blind Reading Print by Sound}

Several devices have been invented with the view of enabling the blind to read ordinary print instead of Braille. As mentioned in Nature of Jan. 9, p. 52, the 'optophone' was invented by Dr. Fournier d'Albe and the 'phonopticon' by Prof. F. C. Browne. These two instruments convert ordinary type directly into sound signals ; but according to Dr. Ernest Whitfield, of the National Institute for the Blind, London, neither is in use in any institution for the blind. We understand also that there is no alphabet requiring more training than one which converts printing into sound. The 'photoelectrograph' of MM. Thomas and Conland, as announced in our note, involves touch ; but since the Braille type part of the machine would necessitate the printing of books in special type, it would involve a cost beyond the reach of the average blind person. We have also been reminded of other instruments for aiding the blind, including the 'optograph' of Dr. J. Butler Burke, which involves the use of a photoelectric cell to convert typewritten or printed matter into Braille, and also sets up type automatically; this instrument was exhibited at the Exhibition of Inventions in October 1929. Another instrument is the "visagraph' invented by Mr. Robert E. Naumburg, of Cambridge, Mass. This latter involves touch, a ray of light passing over the printed page, and the letters are reproduced in embossed type on a sheet of aluminium foil. It may be remarked that embossed 'roman type' preceded Braille, and Dr. Whitfield states that it was very successful. The 'visagraph' is being used successfully in America, thus showing that ordinary type is suitable for reading by touch with reasonable speed.

\section{New Political Fellowship}

THE present state of party politics has given an impetus to non-party movements such as the New Political Fellowship organised by Mr. A. G. Pape, though it is perhaps premature to predict as the ultimate outcome the formation of a centre group in our Houses of Parliament. Party polities are apparently insufficient for the present emergency. The cooperative methods advocated by the New Political Fellowship, based on a definite planning of national and international life which is determined by an impartial study of the facts, not by political prejudice, are much more in harmony with the methods and outlook of scientific workers. The Fellowship, which already has a basis in some thirty countries, claims to break with useless traditions, and to substitute for the narrow, national jealousies a broad outlook and a spirit of co-operation which will enable existing international machinery, such as the League of Nations, the International Labour Office, etc., to function smoothly. However idealistic certain of the points in this policy may appear, they undoubtedly spring from the conviction that leadership must be based primarily on knowledge and no longer on prejudice or vested interests. In this the Fellowship can justly ask the support of men of science, without whose support its efforts indeed are likely to be largely sterile. It is only the solutions reached under the guidance of the calm impartial spirit of science that will have permanent value and authority in the era of co-operation which the Fellowship seeks to promote.

\section{Charles II. Exhibition in London}

THE period of Charles II. is so intimately connected with the beginnings of some of our principal scientific institutions that it is satisfactory to record that the Royal Society, the Greenwich Observatory, the Old Ashmolean Museum, Chelsea Hospital, and Hudson's Bay Company, all dating from his reign, should be joining in contributing contemporary exhibits to the Loan Exhibition now being held at 22 Grosvenor Place, London. The scientific exhibits include the

No. 3252, VoL. 129] 